\title{
Agricultural Product Traceability: Current Needs, the Existing Problems and the Corresponding Suggestions
}

\author{
Yandan Wang ${ }^{1, a}$ and Xiangyu Zhang ${ }^{2, b}$ \\ ${ }^{1}$ Economic and Management Department, Tianjin University of Science \& Technology, Tianjin \\ 300222, China \\ ${ }^{2}$ Food Engineering and Biotechnology Department, Tianjin University of Science \& Technology, \\ Tianjin 300222, China \\ a393130193@qq.com, b373152711@qq.com
}

Key words: agricultural products; traceability

Abstract: Market globalization and frequent food safety incidents have resulted in consumers' much awareness of the need of food traceability. The objective of this paper is to analyze the current needs and problems of agricultural product traceability in China, and to summarize the achievements and shortcomings of Chinese quality traceability system's construction. Through research and analysis of quality traceability system of agricultural products in developed countries, the paper suggests that agricultural product traceability is key to enforce food safety regulations. Moreover, some countermeasures are proposed for improving the Chinese quality traceability system of agricultural products.

\section{Introduction}

Nowadays, agricultural product is the most traded food commodity in the world ${ }^{[1]}$. The food safety incidents of pesticide residues, veterinary drug residues and heavy metals and other toxic substances happen sometimes. The quality and safety of agricultural products caused some confusion and panic. How to find the origin of the issue is the problem we need to solve.

China initially established a agricultural product quality traceability system to monitor quality and safety of agricultural products. Through investigation and comparison of domestic and foreign agricultural traceability systems, we propose the countermeasures for improving the Chinese quality traceability system of agricultural products.

\section{Agricultural Product Traceability}

Traceability is critical to guarantee the quality of food products and minimize food safety risks. If a contaminated product is detected on the global market, the information provided by traceability should make it possible to easily trace back the origin of the problem, thus facilitating the application of an effective contingency plan and clarification of responsibilities. Traceability also provides a product value guarantee that fulfills the demand of modern consumers for high-quality standards, which is particularly relevant for agricultural product products ${ }^{[2]}$.

Agricultural product traceability system is a measure which can record and monitor the various stages of the market from production to distribution of the whole process, helping quality control and recall problematic products. According to the definition of the Codex Alimentarius Commission (CAC) and the International Organization for Standardization (ISO), the traceability system (TS) can be expressed as: " we have the ability to trace the products through the registration identification code of the goods or behavioral history. "

\section{Domestic Agricultural Product Traceability System}

In China traceability of food safety research and implementation of the system is relatively late, but we also have made remarkable achievements. At the same time, we also develop national standards 
and guidelines of relatively mature traceability system. Table 1 summarizes main Agricultural product traceability acts of China.

Table 1 Main agricultural product traceability acts of China

\begin{tabular}{|c|c|c|}
\hline Act & Release date & The main contents \\
\hline $\begin{array}{l}\text { 《Shanghai Edible } \\
\text { Agricultural Products } \\
\text { Safety Supervision } \\
\text { Interim Measures》 }\end{array}$ & July 23, 2001 & $\begin{array}{l}\text { To improve the } \\
\text { traceability system of } \\
\text { agricultural products’ } \\
\text { quality and safety }\end{array}$ \\
\hline $\begin{array}{l}\text { 《People's Republic of } \\
\text { China Agricultural } \\
\text { Product Quality and } \\
\text { Safety Act》》 }\end{array}$ & November 1, 2006 & $\begin{array}{l}\text { The department of } \\
\text { agriculture administration } \\
\text { shall take management } \\
\text { measures based on the risk } \\
\text { assessment result of } \\
\text { agricultural products' } \\
\text { quality and safety }\end{array}$ \\
\hline $\begin{array}{r}\text { 《People's Republic of } \\
\text { China Food Safety Law》 }\end{array}$ & March 8, 2015 & $\begin{array}{l}\text { Requiring producers to } \\
\text { establish food traceability } \\
\text { system to ensure food } \\
\text { traceability }\end{array}$ \\
\hline
\end{tabular}

Shanghai in July 2001 issued a Food Safety Supervision Interim Measures of Agricultural Products in Shanghai, which pointed out the traceability system of various circulation establish files market. The official traceability system will be applied in the quality of supervision and safety of agricultural products. After a few years, our country with its own national conditions and issued a Beef Products Traceability Guidelines, Food Safety Law and other relevant legal documents. Beijing uses radio frequency identification (RFID) technology and computer management system for beef and pork to establish a traceability management system. In addition, Shandong conducted research in vegetable base about vegetable safety traceability system information to identify the identity of agricultural products. Nanjing Agricultural Products also launched a IC Card Management System. The implemented of traceability system standardized corporate chain greatly enhance the country's food safety credit system ${ }^{[3-4]}$.

Beginning in 2010, the Ministry of Commerce began to implement meat and vegetables development pilot. In Beijing and other places on the Cornish circulation process of building a traceability system on the market of information technology and efficient management of food safety in order to achieve the overall supportability, and Cornish origin of products, distribution channels can do certified investigation, the relevant departments in a timely manner conducive to accountability. In the same year, it was held on the construction of Qingdao meat traceability system circulation forum and through the acceptance of the first batch traceability system pilot cities, as one of the pilot cities to establish traceability. In addition, Qingdao is also the production and distribution of vegetables and export models combine the implementation of the "basket" program to increase its level of food safety. Lin Zhipeng used Web Service technology to build things food traceability system to solve the interaction of different information between different enterprises, which made food traceability system operate effectively ${ }^{[5]}$. Yang Liang used of cattle individual coding technology, RFID electronic ear tag technology, information acquisition and wireless network transmission technology, Hazard Analysis and Critical Control Point (HACCP) control system to establish a large-scale cattle traceability system ${ }^{[6]}$.

Stage implementation of agricultural products can be traced back mainly use the computer to start from all aspects of agricultural production, transportation and sales. Meanwhile, the equal government also has a certain impact for the implementation of traceability systems. Jiang Liqing, used Logistic model to analyze willingness of government and farmers in traceability system, found that the government behavior is largely influenced farmers are involved in the management of traceability $^{[7]}$. Shao Wenge analyzed the current situation of agricultural products cold chain logistics 
and put forward that the industry should have government support, encouragement and training of personnel $^{[8]}$.

China's food traceability system though has been in development, it is still in its early stages. There is still a gap between developed countries and China. Such as food safety laws and regulations is not perfect, private individual producers and traders are difficult to implement traceability management, consumer awareness of the traceability of the product price is not deep, the level of information food traceability construction is still very low, and so on.

\section{Foreign Agricultural Product Traceability System}

Internationally, United States, European Union and other developed areas claim that part of the export and local products must have a traceability system, otherwise it can not flow to the market. The traceability system not only can effectively ensure food safety and hygiene, but also to enhance China's international trade market. The UK in 1997 developed the livestock traceability system. Currently, some EU countries establish a traceability system for the part of livestock and their products, in which the most representative is the cattle and meat traceability system. The system has achieved from breeding to all aspects of the circulation. Table 2 summarizes main Agricultural product traceability acts of European Union.

Table 2 Main agricultural product traceability acts of EU

\begin{tabular}{|c|c|c|}
\hline$\overline{\text { Act }}$ & Release date & The main contents \\
\hline $\begin{array}{l}\text { 《White Paper on Food } \\
\text { Safety》 }\end{array}$ & January 12, 2000 & $\begin{array}{l}\text { Creating an international } \\
\text { food safety control system } \\
\text { to keep the Member States } \\
\text { in a coordinated operation } \\
\text { to provide consumers with } \\
\text { adequate food safety and } \\
\text { risk information and other } \\
\text { required information }\end{array}$ \\
\hline $\begin{array}{l}\text { 《The Act of No. } \\
931 / 2011 》\end{array}$ & September 19, 2011 & $\begin{array}{l}\text { For specific foods of } \\
\text { animal origin, the dealers } \\
\text { and distributors are } \\
\text { required to provide sub } \\
\text { distributors with food } \\
\text { details }\end{array}$ \\
\hline $\begin{array}{l}\text { 《The Act of No. } \\
\text { 208/2013》 }\end{array}$ & March 11, 2013 & $\begin{array}{l}\text { It makes provision for the } \\
\text { seed sprouts and at all } \\
\text { stages of production, } \\
\text { processing and marketing } \\
\text { of traceability }\end{array}$ \\
\hline
\end{tabular}

In 2002, the US Congress passed the Bioterrorism Act to enhance food safety issues to unprecedented heights, and promulgated the from farm to table implementation of risk management policy. The policy is clear that the agricultural product traceability system will be divided into three categories. The first is agricultural production chain traceability system. The second is packaging, processing and transportation sectors traceability system. The third is sales process traceability system. The United States has established relatively mature stage of agricultural products traceability system. For example, the United States clearly stated to develop a related project through US 2009 Food Safety Strengthening Act so that the recipient can quickly and efficiently identify and mitigate food borne disease and other hazards. At 208/2013 bill, it puts forward specific requirements to the establishment of food traceability system. Table 3 summarizes main Agricultural product traceability acts of United States. 
Table 3 Main agricultural product traceability acts of US

\begin{tabular}{|c|c|c|}
\hline$\overline{\mathrm{Act}}$ & Release date & The main contents \\
\hline 《Bioterrorism Act $\rangle$ & June 12, 2002 & $\begin{array}{l}\text { It requires practitioners to } \\
\text { establish and maintain } \\
\text { records of food } \\
\text { production, processing, } \\
\text { packaging, transportation, } \\
\text { distribution, receipt, } \\
\text { storage, or import food } \\
\text { sources. }\end{array}$ \\
\hline $\begin{array}{l}\text { 《US } 2009 \text { Food Safety } \\
\text { Strengthening Act } 》\end{array}$ & July 30, 2009 & $\begin{array}{l}\text { The establishment of the } \\
\text { United States food } \\
\text { traceability system to } \\
\text { determine the technology } \\
\text { to track the history and } \\
\text { circulation of food }\end{array}$ \\
\hline $\begin{array}{l}\text { 《Interstate Movement of } \\
\text { livestock Traceability } \\
\text { Final Bill》 }\end{array}$ & January 9, 2013 & $\begin{array}{l}\text { To establish simplest } \\
\text { official identification and } \\
\text { documentation } \\
\text { requirements for livestock } \\
\text { traceability of interstate } \\
\text { movement }\end{array}$ \\
\hline
\end{tabular}

Food safety issues are also of concern in South Korea. The production association began the trial related about traceability systems of animal products, fresh fruits and vegetables since 2004. In 2005 the South Korean government enacted the Agricultural Products Quality Control Act to precise definite the agricultural products traceability program and begin the implementation of the Act and in January 2006 across the country. From the beginning of 2015, South Korean Agriculture Food and Rural Affairs said that the pilot project in October 2004 has been completed. Meanwhile, Cattle and Beef Traceability Act has been complete revision, in which other livestock products such as pork can be traced back. Table 4 summarizes main Agricultural product traceability acts of South Korea.

Table 4 Main agricultural product traceability acts of South Korea

\begin{tabular}{|c|c|c|}
\hline Act & Release date & The main contents \\
\hline $\begin{array}{l}\text { 《Food Safety Basic } \\
\text { Law》 }\end{array}$ & June 1, 2012 & $\begin{array}{l}\text { Government agencies } \\
\text { must promote the } \\
\text { establishment of tracking } \\
\text { mechanism for food } \\
\text { production, sales process }\end{array}$ \\
\hline $\begin{array}{l}\text { 《Cattle and Beef } \\
\text { Traceability Act》 }\end{array}$ & May 23, 2012 & $\begin{array}{l}\text { Specific requirements of } \\
\text { traceability for beef }\end{array}$ \\
\hline
\end{tabular}

\section{Improvement and suggestion for the Chinese quality traceability system of agricultural products.}

Table 5 shows that the comparison of traceability systems between many major developed economies and china, it can be seen that the traceability systems has been developed in seven different aspects: a. the development and integration of traceability standards and relevant laws of traceability mechanisms.

b. the rights and responsibilities involved in the coordination of retroactive persons.

c. the integration of traceability information, traceability improvement and efficiency.

d. simplify traceability cell information.

e. convenience of traceability process.

f. unified coding scheme. 
g. refinement of different agricultural traceability information to get more accurate traceability information.

Table 5 Comparative analysis of agricultural product traceability in developed economies

\begin{tabular}{|c|c|c|c|}
\hline Economies & $\begin{array}{l}\text { Implement } \\
\text { programme }\end{array}$ & Traceability system & Main features \\
\hline European Union & $\begin{array}{l}\text { In accordance with } \\
\text { their own } \\
\text { circumstances,mem } \\
\text { ber states use } \\
\text { different systems. } \\
\text { British beef } \\
\text { traceability system } \\
\text { is central, others are } \\
\text { decentralized. }\end{array}$ & $\begin{array}{l}\text { Animal traceability } \\
\text { system is central, } \\
\text { others are } \\
\text { decentralized in } \\
\text { information } \\
\text { architecture }\end{array}$ & $\begin{array}{c}\text { A "step up, step } \\
\text { down" traceability } \\
\text { mode }\end{array}$ \\
\hline United States & $\begin{array}{l}\text { Establishing } \\
\text { national animal } \\
\text { traceability system, } \\
\text { with industry } \\
\text { associations and } \\
\text { enterprises setting } \\
\text { up independent } \\
\text { tracking system }\end{array}$ & $\begin{array}{l}\text { Animal traceability } \\
\text { system is central, } \\
\text { others are } \\
\text { decentralized in } \\
\text { information } \\
\text { architecture }\end{array}$ & $\begin{array}{c}\text { Focus on } \\
\text { cross-border } \\
\text { transport of animals } \\
\text { and management } \\
\text { and tracking of } \\
\text { animal diseases }\end{array}$ \\
\hline South Korea & $\begin{array}{l}\text { National uniform } \\
\text { implementation in } \\
\text { livestock, fisheries } \\
\text { and agricultural } \\
\text { products with GAP } \\
\text { certification are } \\
\text { required to do } \\
\text { mandatory } \\
\text { traceability }\end{array}$ & $\begin{array}{l}\text { Livestock, aquatic } \\
\text { products, fruits and } \\
\text { vegetables are } \\
\text { central traceability } \\
\text { in information } \\
\text { architecture }\end{array}$ & $\begin{array}{l}\text { Using registration, } \\
\text { inspection, } \\
\text { correcting, quit } \\
\text { mechanisms etc. to } \\
\text { improve } \\
\text { traceability }\end{array}$ \\
\hline China & $\begin{array}{l}\text { Government } \\
\text { promotes the } \\
\text { implementation of } \\
\text { traceability systems } \\
\text { and stipulates } \\
\text { specific tracking } \\
\text { content }\end{array}$ & $\begin{array}{c}\text { Traceability } \\
\text { systemof } \\
\text { agricultural } \\
\text { products is central }\end{array}$ & $\begin{array}{l}\text { Using RFID } \\
\text { technology to } \\
\text { acquire related } \\
\text { information }\end{array}$ \\
\hline
\end{tabular}

Currently the traceability system in China is forging to take the form of multi-pronged, as it involves the interests of all parties so that the progress of the provinces differs and lacks of unified traceability standards, resulting in the promotion and implementation of traceability system is not ideal. More specifically our proposed five countermeasures:

1. The government combine detail legislation planning with agricultural traceability system operation and strengthen import and export of agricultural products traceability requirements. Because of the Europe and other developed economies' traceability requirement of import agricultural products has been strengthened, to some extent it reduces the exports of Chinese agricultural products. In order to ensure economic development and national health, the law-making of traceability system should be further refined.

2. Chinese agricultural products can be used for central focus on fruits and vegetables and other agricultural products with master-slave type to refine traceability information, which promote the integrity of information systems.

3. The government could refer to the mechanism of the United States and the European Union and sets up the unified platform for the implementation of traceability, basing on their own particular circumstances to implement on different agricultural products to promote the overall development of agricultural products traceability at the same time different provinces. 
4. It can take a combination of compulsory and voluntary manner to promote traceability system. Governments use the law to make an important food companies to implement traceability system, while providing financial aid to protect the interests of businesses and consumers.

5. It can also try the traceability transition from the provincial units to agricultural items. From the perspective of agricultural supply chain, the regionalsim of different agricultural production process is significant, but the processing, distribution and marketing chain widespread across the region. It has advantage in ensuring traceability completeness and accuracy by adopting agricultural items ${ }^{[9]}$.

\section{References}

[1] S.A. Starbird and V. Amanor-Boadu: Traceability, moral hazard, and food safety. Ssrn Electronic Journal(2008)

[2] Z. Pieniak, F. Vanhonacker and W. Verbeke: Consumer knowledge and use of information about fish and aquaculture. Food Policy (2013)

[3] D. J. Runoff and Reality: Externalities, Economics and Traceability Issues in Urban Runoff Regulation. Social Science Electronic Publishing(2006)

[4] A. Gracia and G. Zeballos: submitted to Journal of Food Distribution Research(2005)

[5] V. K. V, P. Kumar and D. Kumar: Supporting the management of the engineering change process through a cross-domain traceability model. University of Cambridge(2011)

[6] H. H. Wang, R. W. Zhang and D. L. Ortega: Chinese Food Safety Situation in a Globalized World Market. Journal of Chinese Economics(2013)

[7] Q. Gong: The Impact of the Supply Chain Traceability on Food Safety and Corporate Profits. Nankai Economic Studies(2012)

[8] W. P. Fisher and A. J. Stenner: Metrology for the Social, Behavioral, and Economic Sciences. Social Science Electronic Publishing(2011)

[9] L. Valerio: Traceability and Supervision over Payment Systems after the Law Decree No. 201/2011. (2012) 